\title{
Efektivitas ikan pelangi arfak, Melanotaenia arfakensis, Allen 1990 dalam mencari makan pada tingkat kekeruhan air yang berbeda: suatu pendekatan laboratorium
}

[Feeding effectivity of the arfak rainbowfish, Melanotaenia arfakensis, Allen 1990 on difference of water turbidity level: a laboratory approach]

\author{
Emmanuel Manangkalangi ${ }^{1,2,5}$, M. F. Rahardjo ${ }^{3,5}$, Renny K Hadiaty ${ }^{4,5}$, Sigid Hariyadi ${ }^{3}$ \\ ${ }^{1}$ Mahasiswa Program Studi Pengelolaan Sumber Daya Perairan, Sekolah Pascasarjana-IPB, Bogor \\ 2 Jurusan Perikanan, Fakultas Perikanan dan Ilmu Kelautan (FPIK)-UNIPA, Manokwari \\ Jl. Gunung Salju Amban, Manokwari \\ ${ }^{3}$ Departemen Manajemen Sumber Daya Perairan, FPIK-IPB, Bogor \\ ${ }^{4}$ Museum Zoologicum Bogoriense (MZB), Bidang Zoologi, Pusat Penelitian Biologi-LIPI \\ ${ }_{5}$ Masyarakat Iktiologi Indonesia
}

Diterima: 30 Juni 2017; Disetujui: 3 Oktober 2017

\begin{abstract}
Abstrak
Penelitian efektivitas ikan pelangi arfak dalam mencari makan dilaksanakan di Laboratorium Perikanan FPIK Universitas Papua pada bulan Juli sampai Desember 2016. Tujuan penelitian ini untuk mendeskripsikan efektivitas ikan pelangi arfak mencari makan pada beberapa tingkat kekeruhan air. Contoh ikan yang digunakan dalam perlakuan dikoleksi dari Sungai Nimbai, sistem Sungai Prafi, Manokwari yang diaklimatisasi selama satu bulan di laboratorium. Individu ikan yang digunakan dalam penelitian ini dipilih berdasarkan panjang tubuh dan dikelompokkan ke dalam enam kelas ukuran. Setiap individu ikan diberi perlakuan pakan berupa larva nyamuk (tahap instar IV) sebanyak 200 individu pada tujuh tingkat kekeruhan yang berbeda $(2,54 ; 25,07 ; 50,52 ; 100,20 ; 200,20 ; 500,60$ dan 800,40 Nephelometric Turbidity Unit, NTU) dengan menggunakan partikel berukuran $<63 \mu \mathrm{m}$. Efektivitas mencari makan akan ditunjukkan berdasarkan tingkat pemangsaan dalam periode 15 menit. Tingkat pemangsaan rata-rata tidak berbeda pada tingkat kekeruhan yang rendah $(\leq 50,52 \mathrm{NTU})$ dalam setiap kelas ukuran. Penurunan tingkat pemangsaan rata-rata secara nyata mulai berlangsung pada tingkat kekeruhan yang lebih tinggi ( $\geq 100,12 \mathrm{NTU})$ dengan nilai sebesar $23,2 \%-65,9 \%$. Kondisi ini menunjukkan penurunan efektivitas mencari makan seiring dengan semakin meningkatnya tingkat kekeruhan air.
\end{abstract}

Kata penting: Melanotaenia arfakensis, mencari makan, tingkat kekeruhan

\begin{abstract}
The research on feeding effectivity of arfak rainbowfish conducted at Fisheries Laboratory, Faculty of Fishes and Marine Scince, University of Papua in July to December 2016. The purpose of this research is to describe feeding effectivity of the fish at several levels of water turbidity. The fish samples used in the treatment, collected from Nimbai Stream, Prafi River system, Manokwari were acclimatized for a month in the laboratory. The fish were selected based on the body length and categorized into six size classes. Each individual of the fish was treated with 200 individuals of mosquito larvae (instar IV stage) at seven turbidity levels $(2.54,25.07,50.52,100.20,500.60$, and 800.40 Nephelometric Turbidity Unit, NTU) using particles with size of $<63 \mu \mathrm{m}$. Feeding effectivity was indicated by the level of predation in a period of 15 minutes. The results of the research showed that average level of predation did not differ among size classes at the low level of turbidity $(\leq 50,52 \mathrm{NTU})$. The significant decrease in the average level of predation occurred at the higher level of turbidity ( $\geq 100,12 \mathrm{NTU}$ ) with the values range from $23.2 \%$ to $65.9 \%$. This indicated a decrease in the feeding effectivity as the turbidity levels increase.
\end{abstract}

Keywords: Melanotaenia arfakensis, feeding, turbidity level

\section{Pendahuluan}

Perubahan kondisi perairan sungai dalam kaitannya dengan aktivitas antropogenik telah banyak dilaporkan, di antaranya berkaitan dengan pembukaan areal hutan, termasuk konversi

$\triangle$ Penulis korespondensi

Alamat surel: e_manangkalangi2013@yahoo.com zona riparia di bagian tepi sungai (dos Santos et al. 2015, Lorion \& Kennedy 2009, Lobón-Cerviá et al. 2016) untuk perkebunan dan pertanian (Bojsen \& Barriga 2002, Iwata et al. 2003, Wright \& Flecker 2004, Cassatti et al. 2009, Mercer et al. 2013, Giam et al. 2015, Mori et al. 2015), dan pembuatan infrastruktur, misalnya ja- 
lan (Wang et al. 2013), serta aktivitas pertambangan (Mol \& Ouboter 2004, Batsaikhan et al. 2017). Salah satu bentuk perubahan tersebut adalah meningkatnya kekeruhan air akibat dari masukan partikel tersuspensi ke dalam sistem sungai (Growns \& Davis 1994, Sutherland et al. 2002, dos Santos et al. 2015). Beberapa penelitian sebelumnya telah menunjukkan adanya pengaruh meningkatnya masukkan partikel tersuspensi dan kekeruhan terhadap komunitas ikan dan makroavertebrata, termasuk insekta air, sebagai komponen dalam jejaring makanan di sungai. Beberapa jenis ikan cenderung menghindari perairan yang keruh karena akan mengurangi kemampuan mencari makan secara efektif (Berg \& Northcote 1985, Bruton 1985, Vogel \& Beauchamp 1999, Sweka \& Hartman 2003, Sutherland \& Meyer 2007, Zamor \& Grossman 2007) berkaitan dengan menurunnya jarak reaktif ikan secara visual ketika mencari makan (Barrett et al. 1992, Shoup \& Wahl 2009, Carter et al. 2010) dan/atau kecepatan ikan dalam mencari makan (Rowe \& Dean 1998). Kondisi ini akan berakibat pada penurunan laju pertumbuhan ikan (Sigler et al. 1984, Northcote 1995), kelimpahan dan penyebarannya (Berkman \& Rabeni 1987, Rowe et al. 2000, Mol $\&$ Ouboter 2004). Pada kelompok makroavertebrata air, pengaruh tingkat kekeruhan di antaranya menurunkan kepadatan dan keanekaragaman (Growns \& Davis 1994, Gleason et al. 2003, Connolly \& Pearson 2007, Couceiro et al. 2010), serta mengubah struktur trofiknya (Henley et al. 2000, Couceiro et al. 2011).

Ikan pelangi arfak (Melanotaenia arfakensis) adalah salah satu ikan endemik di Papua, khususnya pada beberapa sistem sungai di sekitar Manokwari, di antaranya Sungai Prafi (Allen 1990, 1991), S. Warmare, S. Madrad, S. Subsay, S. Aimasi, S. Nimbai (Tapilatu \& Renyaan 2005, Sabariah et al. 2006a,b, Manangkalangi et al. 2009a,b, 2010, Manangkalangi \& Kaliele 2011), dan S. Nuni, S. Pami (Sabariah 2004, Sabariah et al. 2005), dan sistem sungai di sebelah barat $\mathrm{S}$. Wariori (Binur \& Budirianto 2008), S. Api, S. Atai, S. Asiti dan S. Ani (Manangkalangi \& Pattiasina 2005, Sabariah et al. 2006b, Kadarusman et al. 2012). Ikan ini termasuk kelompok insektivora dan komposisi makanannya terutama didominasi oleh larva insekta air dari kelompok Diptera, Ephemeroptera, Coleoptera, dan Trichoptera (Manangkalangi et al. 2010).

Berdasarkan penelitian sebelumnya, dilaporkan bahwa kondisi habitat alami ikan ini semakin menurun berkaitan dengan berbagai aktivitas antropogenik (Manangkalangi et al. 2014), di antaranya diduga berkaitan dengan konversi hutan menjadi perkebunan kelapa sawit dan persawahan. Perubahan ini akan meningkatkan erosi bagian tepi sungai dan aliran permukaan yang membawa partikel dari daratan ke sungai (Mercer et al. 2013), dan selanjutnya akan menyebabkan peningkatan masukan partikel tersuspensi dan kekeruhan dalam kolom air sungai. Berkaitan dengan perubahan kondisi habitat ini, maka penelitian perlu dilakukan untuk mendeskripsikan efektivitas ikan pelangi arfak mencari makan dalam kaitannya dengan kondisi kekeruhan air.

\section{Bahan dan metode}

Lokasi dan waktu penelitian

Pengumpulan contoh ikan pelangi arfak ( $M$. arfakensis) pada penelitian ini diambil dari $\mathrm{Su}-$ ngai Nimbai, sistem Sungai Prafi yang terletak di daerah ritral berdasarkan penelitian sebelumnya (Manangkalangi et al. 2009a, Manangkalangi \& Kaliele 2011, Manangkalangi et al. 2014). Aklimatisasi dan pengujian tingkat kekeruhan dilakukan di Laboratorium Perikanan - FPIK -Universitas Papua. Pengumpulan contoh ikan, akli- 
matisasi dan pengujian tingkat kekeruhan berlangsung dari bulan Juli sampai Desember 2016.

\section{Koleksi dan aklimatisasi contoh ikan}

Contoh ikan yang telah dikumpulkan dibawa ke laboratorium dan dipelihara dalam akuarium berukuran $80 \mathrm{~cm}$ x $35 \mathrm{~cm} \mathrm{x} 40 \mathrm{~cm}(112 \mathrm{~L})$. Kondisi kualitas air disesuaikan dengan habitat alaminya (Tabel 1) (Manangkalangi et al. 2009a, Manangkalangi et al. 2014). Proses aklimatisasi dalam skala laboratorium dilakukan selama satu bulan dengan menggunakan pakan larva nyamuk (Cullicidae) tahap instar IV.

Koleksi dan penanganan larva nyamuk sebagai makanan dalam uji tingkat kekeruhan

Larva nyamuk dikoleksi dari genangan di sekitar Kampus UNIPA dan permukiman masyarakat secara harian. Larva nyamuk yang diperoleh dibilas dalam air bersih dan dipilih berdasarkan tahap perkembangan (yaitu, instar IV). Pemilihan tahap instar IV Cullicidae ini berkaitan dengan hasil penelitian sebelumnya, yaitu kelompok mangsa ini ditemukan dalam lambung (Manangkalangi et al. 2010) dan juga tingkat pemangsaannya yang tinggi oleh ikan pelangi arfak dalam percobaan sebagai biokontrol (Manangkalangi et al. 2015). Selain itu, ukurannya yang relatif cukup besar dan aktif dalam pergerakannya (Colless \& McAlpine 1996). Kondisi ini relatif memudahkan dalam pemilahan dan terkait dengan reaksi makan ikan yang terutama terkait dengan pergerakan mangsa (Crowl 1989, Utne-Palm 1999). Ukuran rata-rata (kisaran) panjang tubuh dan lebar thoraks tahap instar IV yang digunakan dalam penelitian ini berturut-turut, yaitu: 5,34 (4,60-6,57) $\mathrm{mm}$ dan $1,41(0,90-1,75) \mathrm{mm}$.

Koleksi, pemilihan ukuran partikel sedimen, dan pengukuran tingkat kekeruhan

Contoh sedimen dikumpulkan dari lokasi habitat alami ikan pelangi arfak di S. Nimbai. Contoh sedimen kemudian dikeringkan dalam oven selama dua hari pada suhu $60^{\circ} \mathrm{C}$. Selanjutnya sedimen dipilah berdasarkan ukuran dengan menggunakan ayakan bertingkat yang dilengkapi dengan shecker. Gambaran tingkat kekeruhan didapatkan dengan cara memilih ukuran partikel yang dominan tersuspensi di perairan, yaitu kategori lempung dan liat $(<63$ $\mu \mathrm{m})$ (Lenzi \& Marchi 2000, Walling et al. 2000). Dalam pengujian ini digunakan tujuh kategori tingkat kekeruhan (Tabel 2), berdasarkan hasil penelitian sebelumnya (Tapilatu \& Renyaan 2005, Manangkalangi 2009) dan pengukuran in situ contoh air di Sungai Nimbai dalam periode April-Desember 2016 (Tabel 3). Pengukuran tingkat kekeruhan dilakukan menggunakan Hanna Instrument 93703 microprocessor turbidity meter dengan kisaran ukuran 0,00-1.000 NTU.

Tabel 1. Karakteristik kualitas air di habitat alami ikan pelangi arfak dan di laboratorium

\begin{tabular}{lccccl}
\hline \multicolumn{1}{c}{ Lokasi } & Suhu $\left({ }^{\circ} \mathrm{C}\right)$ & $\begin{array}{c}\text { Oksigen terlarut } \\
\left(\mathrm{mg} \mathrm{L}^{-1}\right)\end{array}$ & $\mathrm{pH}$ & $\begin{array}{c}\text { Intensitas } \\
\text { cahaya (lux) }\end{array}$ & \multicolumn{1}{c}{ Sumber } \\
\hline $\begin{array}{l}\text { Sungai Nimbai } \\
\text { dan S. Aimasi }\end{array}$ & $24,6-28,6$ & $5,2-7,5$ & $7,9-8,6$ & - & Manangkalangi et al. (2009a) \\
$\begin{array}{l}\text { S. Nimbai } \\
\text { Laboratorium }\end{array}$ & $24,0-27,5$ & $5,06-6,87$ & $6,63-7,98$ & - & Manangkalangi et al. $(2014)$ \\
\hline
\end{tabular}


Tabel 2. Kategori tingkat kekeruhan yang digunakan dalam percobaan.

\begin{tabular}{ccc}
\hline Kategori Tingkat Kekeruhan & Kisaran (NTU) & Rata-rata \pm SD (NTU) \\
\hline I & $0,87-6,18$ & $2,54 \pm 2,15$ \\
II & $21,08-27,24$ & $25,07 \pm 2,63$ \\
III & $42,94-64$ & $50,52 \pm 8,20$ \\
IV & $76-120$ & $100,20 \pm 16,62$ \\
V & $172-220$ & $200,20 \pm 20,93$ \\
VI & $442-583$ & $500,60 \pm 53,24$ \\
VII & $722-856$ & $800,40 \pm 59,52$ \\
\hline
\end{tabular}

Tabel 3. Tingkat kekeruhan habitat ikan pelangi arfak di beberapa sungai dalam sistem Sungai Prafi

\begin{tabular}{llcl}
\hline \multicolumn{1}{c}{ Lokasi } & \multicolumn{1}{c}{ Periode Waktu } & $\begin{array}{c}\text { Tingkat Kekeruhan } \\
(\text { NTU) }\end{array}$ & Sumber \\
\hline S. Nimbai & Juni-Desember 2007 & $0,16-2,97$ & Manangkalangi (2009) \\
S. Aimasi & Juli-Desember 2007 & $0,97-5,03$ & \\
$\begin{array}{l}\text { Beberapa anak sungai } \\
\text { dalam sistem S. Prafi }\end{array}$ & Mei-Agustus 1999 & $24,6-58,1$ & Tapilatu \& Renyaan (2005) \\
S. Nimbai & April-Desember 2016 & $\sim 160,33$ & Pengukuran insitu \\
\hline
\end{tabular}

\section{Rancangan percobaan tingkat kekeruhan}

Contoh ikan dipilih berdasarkan ukuran panjang total dan ukuran kali pertama matang gonad (pembagian di antara yuwana dan dewasa) (Manangkalangi et al. 2009b). Dalam percobaan ini, setiap individu ikan dikelompokkan ke dalam kelas ukuran panjang total 20-30 mm, 30-40 mm, 40-50 mm, 50-60 mm, 60-70 mm, dan >70 mm. Pengukuran panjang total setiap individu ikan dilakukan menggunakan teknik fotografi pada setiap individu yang dipilih dalam akuarium berskala.

Setiap individu ikan yang telah diseleksi berdasarkan kelas ukuran ditempatkan dalam akuarium berukuran $35 \mathrm{~cm}$ x $21 \mathrm{~cm}$ x $25 \mathrm{~cm}$ yang berisi 10 liter air secara terpisah dengan tingkat kekeruhan sesuai dengan perlakuan. Sebelum percobaan pemberian mangsa, semua ikan tidak diberi makan selama 24 jam untuk membakukan tingkat kelaparan (Jacob et al. 1983, Russell et al. 2001, Willems et al. 2005, Bhattacharjee et al. 2009, Gupta \& Banerjee
2013, Saleeza et al. 2014). Selanjutnya setiap individu dalam kelompok ukuran diberi perlakuan menggunakan instar yang berukuran relatif seragam (tahap IV) sebanyak 200 individu (Manangkalangi et al. 2015).

Jumlah instar yang dikonsumsi setiap individu ikan selama periode 15 menit dihitung. Pemilihan periode waktu ini berdasarkan Gupta \& Banerjee (2013) yang menemukan bahwa sebagian besar predasi terhadap larva nyamuk berlangsung dalam periode tersebut. Penentuan tingkat pemangsaan setiap individu ikan diperoleh dari jumlah mangsa yang diberikan (200 individu) dikurangi dengan jumlah mangsa yang tersisa dalam akuarium setelah periode 15 menit. Tingkat konsentrasi gas oksigen terlarut dan tingkat kekeruhan air dijaga dengan cara memberi aerasi di setiap akuarium (Bonner \& Wilde 2002), dan diukur sesaat sebelum dilakukan perlakuan. Dalam percobaan ini (6 kelas ukuran panjang tubuh dan 7 tingkat kekeruhan) dilakukan sebanyak 10 ulangan $(\mathrm{n}=420)$. 
Analisis

Analisis ragam satu faktor digunakan untuk menguji hipotesis nol bahwa rata-rata jumlah mangsa (tingkat pemangsaan) tidak dipengaruhi oleh tingkat kekeruhan. Selanjutnya dilakukan uji $\mathrm{t}$ untuk nilai rata-rata tingkat pemangsaan dari perlakuan tingkat kekeruhan dalam setiap kelas ukuran ikan secara berpasangan. Untuk memetakan model konsumsi mangsa berdasarkan kelas ukuran sebagai fungsi dari tingkat kekeruhan digunakan regresi eksponensial, yaitu:

$$
Y_{i}=a e^{b X_{i}} .
$$

$\mathrm{Y}_{\mathrm{i}}$ adalah jumlah dari mangsa yang dikonsumsi pada percobaan ke-i, $\mathrm{X}_{\mathrm{i}}$ adalah tingkat kekeruhan dalam percobaan ke-i, a, dan b adalah koefisien regeresi. Analisis ini dikerjakan dengan menggunakan program MS-Excell 2010.

\section{Hasil}

Hasil penelitian ini menunjukkan bahwa perbedaan tingkat pemangsaan dalam setiap kelas ukuran dipengaruhi oleh tingkat kekeruhan $(P<0,05)$ (Tabel 4). Tingkat pemangsaan akan semakin menurun dengan semakin meningkatnya tingkat kekeruhan (Tabel 5, Gambar 1). Tingkat pemangsaan rata-rata dalam setiap kelas ukuran tidak berbeda nyata $(P>0,05)$ di antara tingkat kekeruhan yang rendah ( $\leq 50,52 \mathrm{NTU})$, dan sebagian mulai berbeda nyata $(P<0,05)$ pada tingkat kekeruhan yang lebih tinggi ( $\geq 100,12$ NTU) (Tabel 5).

Tabel 4. Analisis ragam satu faktor di antara rata-rata tingkat pemangsaan dalam setiap kelas ukuran ikan pelangi arfak pada berbagai tingkat kekeruhan yang berbeda.

\begin{tabular}{ccc}
\hline Kelas Ukuran $(\mathrm{mm})$ & Nilai F & Nilai $P$ \\
\hline $20,0-29,9$ & $4,52^{*}$ & 0,0007 \\
$30,0-39,9$ & $4,00^{*}$ & 0,0019 \\
$40,0-49,9$ & $4,24^{*}$ & 0,0012 \\
$50,0-59,9$ & $4,93^{*}$ & 0,0003 \\
$60,0-69,9$ & $6,39^{*}$ & 0,00003 \\
$\geq 70$ & $11,69^{*}$ & 0,00000001 \\
\hline
\end{tabular}

Keterangan: *berbeda nyata pada $P<0,05$.

Tabel 5. Tingkat pemangsaan rata-rata (individu mangsa per individu ikan) dalam setiap kelas ukuran ikan pelangi arfak pada berbagai tingkat kekeruhan yang berbeda.

\begin{tabular}{cccccccc}
\hline \multirow{2}{*}{$\begin{array}{c}\text { Kelas ukuran } \\
(\mathrm{mm})\end{array}$} & 2,54 & 25,07 & 50,52 & 100,12 & 200,20 & 500,60 & 800,40 \\
\cline { 2 - 7 } $20,0-29,9$ & $22,7^{\mathrm{a}}$ & $20,6^{\mathrm{a}, \mathrm{b}}$ & $19,8^{\mathrm{a}, \mathrm{b}}$ & $15,2^{\mathrm{b}, \mathrm{c}, \mathrm{d}}$ & $15,9^{\mathrm{b}, \mathrm{c}}$ & $11,3^{\mathrm{c}, \mathrm{d}}$ & $11,0^{\mathrm{d}}$ \\
& $(12-36)$ & $(10-30)$ & $(8-33)$ & $(6-30)$ & $(6-24)$ & $(5-16)$ & $(5-21)$ \\
$30,0-39,9$ & $27,3^{\mathrm{a}}$ & $25,2^{\mathrm{a}, \mathrm{b}}$ & $19,6^{\mathrm{b}}$ & $20,3^{\mathrm{a}, \mathrm{b}}$ & $16,6^{\mathrm{b}, \mathrm{c}}$ & $11,3^{\mathrm{c}}$ & $11,1^{\mathrm{c}}$ \\
& $(16-47)$ & $(9-47)$ & $(9-37)$ & $(8-38)$ & $(7-40)$ & $(4-23)$ & $(2-22)$ \\
$40,0-49,9$ & $29,8^{\mathrm{a}}$ & $29,2^{\mathrm{a}}$ & $28,9^{\mathrm{a}}$ & $21,6^{\mathrm{a}, \mathrm{b}}$ & $17,6^{\mathrm{a}, \mathrm{b}}$ & $17,6^{\mathrm{b}}$ & $14,4^{\mathrm{b}}$ \\
& $(14-52)$ & $(13-47)$ & $(17-41)$ & $(8-43)$ & $(5-31)$ & $(5-27)$ & $(6-27)$ \\
$50,0-59,9$ & $69,0^{\mathrm{a}}$ & $57,5^{\mathrm{a}, \mathrm{b}}$ & $56,2^{\mathrm{a}, \mathrm{b}}$ & $53,0^{\mathrm{a}, \mathrm{b}}$ & $38,9^{\mathrm{b}, \mathrm{c}}$ & $30,9^{\mathrm{c}}$ & $23,5^{\mathrm{c}}$ \\
& $(32-121)$ & $(25-120)$ & $(23-102)$ & $(18-92)$ & $(22-77)$ & $(13-53)$ & $(4-47)$ \\
$60,0-69,9$ & $114,1^{\mathrm{a}}$ & $107,8^{\mathrm{a}, \mathrm{b}}$ & $101,5^{\mathrm{a}, \mathrm{b}, \mathrm{c}}$ & $87,2^{\mathrm{b}, \mathrm{c}}$ & $73,0^{\mathrm{c}, \mathrm{d}}$ & $57,1^{\mathrm{d}}$ & $53,0^{\mathrm{d}}$ \\
& $(48-164)$ & $(58-155)$ & $(52-156)$ & $(41-129)$ & $(20-112)$ & $(24-89)$ & $(20-89)$ \\
& $143,2^{\mathrm{a}}$ & $141,4^{\mathrm{a}}$ & $125,6^{\mathrm{a}}$ & $108,5^{\mathrm{a}, \mathrm{b}}$ & $79,3^{\mathrm{b}, \mathrm{c}}$ & $53,4^{\mathrm{c}, \mathrm{d}}$ & $53,3^{\mathrm{d}}$ \\
& $(96-199)$ & $(96-197)$ & $(74-178)$ & $(54-169)$ & $(31-116)$ & $(12-107)$ & $(11-108)$ \\
\hline
\end{tabular}

Keterangan: kisaran tingkat pemangsaan ditampilkan dalam tanda kurung. $* P<0,05$. Tingkat pemangsaan rata-rata yang berbeda secara nyata pada $P<0,05$ dinotasikan dengan huruf di bagian atas yang berbeda. 
Penurunan tingkat pemangsaan rata-rata pada tingkat kekeruhan yang berbeda dalam setiap kelas ukuran ikan pelangi arfak ditampilkan pada Tabel 6. Pada tingkat kekeruhan yang relatif rendah $(\leq 50,52 \mathrm{NTU})$, penurunan tingkat pemangsaan rata-rata pada semua kelas ukuran ikan pelangi arfak relatif kecil $(\leq 28,2 \%)$. Kondisi yang berbeda ditunjukkan pada tingkat kekeruhan yang lebih tinggi ( $\geq 100,12$ NTU). Pada tingkat kekeruhan yang lebih tinggi, penurunan tingkat pemangsaan rata-rata bisa mencapai 23,2\%-65,9\% (Tabel 6).

Model regresi untuk memetakan penurunan tingkat pemangsaan yang diakibatkan pengaruh peningkatan kekeruhan ditampilkan pada Tabel 7 dan Gambar 1. Hasil ini menunjukkan nilai kemiringan (b) yang berbeda dari $0(P<0,05)$. Nilai kemiringan di antara kelas ukuran ikan pelangi arfak berkisar di antara 0,009 dan 0,0013.

Tabel 6. Persentase penurunan tingkat pemangsaan rata-rata dalam setiap kelas ukuran ikan pelangi arfak pada tingkat kekeruhan yang berbeda.

\begin{tabular}{ccccccc}
\hline \multirow{2}{*}{$\begin{array}{c}\text { Kelas Ukuran } \\
(\mathrm{mm})\end{array}$} & \multicolumn{6}{c}{ Persentase Penurunan Tingkat Pemangsaan Berdasarkan Tingkat Kekeruhan (NTU) } \\
\cline { 2 - 7 } & 25,07 & 50,52 & 100,12 & 200,2 & 500,6 & 800,4 \\
\hline $20,0-29,9$ & 9,3 & 12,8 & 33,0 & 30,0 & 50,2 & 51,5 \\
$30,0-39,9$ & 7,7 & 28,2 & 25,6 & 39,2 & 58,6 & 59,3 \\
$40,0-49,9$ & 2,0 & 3,0 & 27,5 & 40,9 & 40,9 & 51,7 \\
$50,0-59,9$ & 16,7 & 18,6 & 23,2 & 43,6 & 55,2 & 65,9 \\
$60,0-69,9$ & 5,5 & 11,0 & 23,6 & 36,0 & 50,0 & 53,5 \\
$>70,0$ & 1,3 & 12,3 & 24,2 & 44,6 & 62,7 & 62,8 \\
\hline Kisaran & $1,3-16,7$ & $3,0-28,2$ & $23,2-33,0$ & $30,0-44,6$ & $40,9-62,7$ & $51,5-65,9$ \\
\hline
\end{tabular}

Keterangan: dasar penentuan yaitu tingkat pemangsaan rata-rata dalam setiap kelas ukuran pada tingkat kekeruhan terhadap tingkat pemangsaan rata-rata pada tingkat kekeruhan yang paling rendah (2,54 NTU).

Tabel 7. Hasil analisis regresi dari pengaruh tingkat kekeruhan terhadap tingkat pemangsaan.

\begin{tabular}{|c|c|c|c|c|c|}
\hline \multirow{2}{*}{ Variabel respon } & \multicolumn{2}{|c|}{ Kemiringan } & \multicolumn{2}{|c|}{ Intersep } & \multirow{2}{*}{$R^{2}$} \\
\hline & $b$ & $P$ & $a$ & $P$ & \\
\hline $20,0-29,9 \mathrm{~mm}$ & $-0,0009^{*}$ & 0,0051 & 19,81 & 0,720 & 0,83 \\
\hline $30,0-39,9 \mathrm{~mm}$ & $-0,0011 *$ & 0,0038 & 23,17 & 0,661 & 0,85 \\
\hline $40,0-49,9 \mathrm{~mm}$ & $-0,0009 *$ & 0,0102 & 26,96 & 0,739 & 0,77 \\
\hline $50,0-59,9 \mathrm{~mm}$ & $-0,0012^{*}$ & 0,0008 & 59,72 & 0,657 & 0,93 \\
\hline $60,0-69,9 \mathrm{~mm}$ & $-0,0010^{*}$ & 0,0017 & 102,73 & 0,644 & 0,88 \\
\hline$\geq 70,0 \mathrm{~mm}$ & $-0,0013 *$ & 0,0015 & 128,63 & 0,546 & 0,86 \\
\hline
\end{tabular}

Keterangan: *berbeda nyata terhadap nilai 0 pada $P<0,05$. 

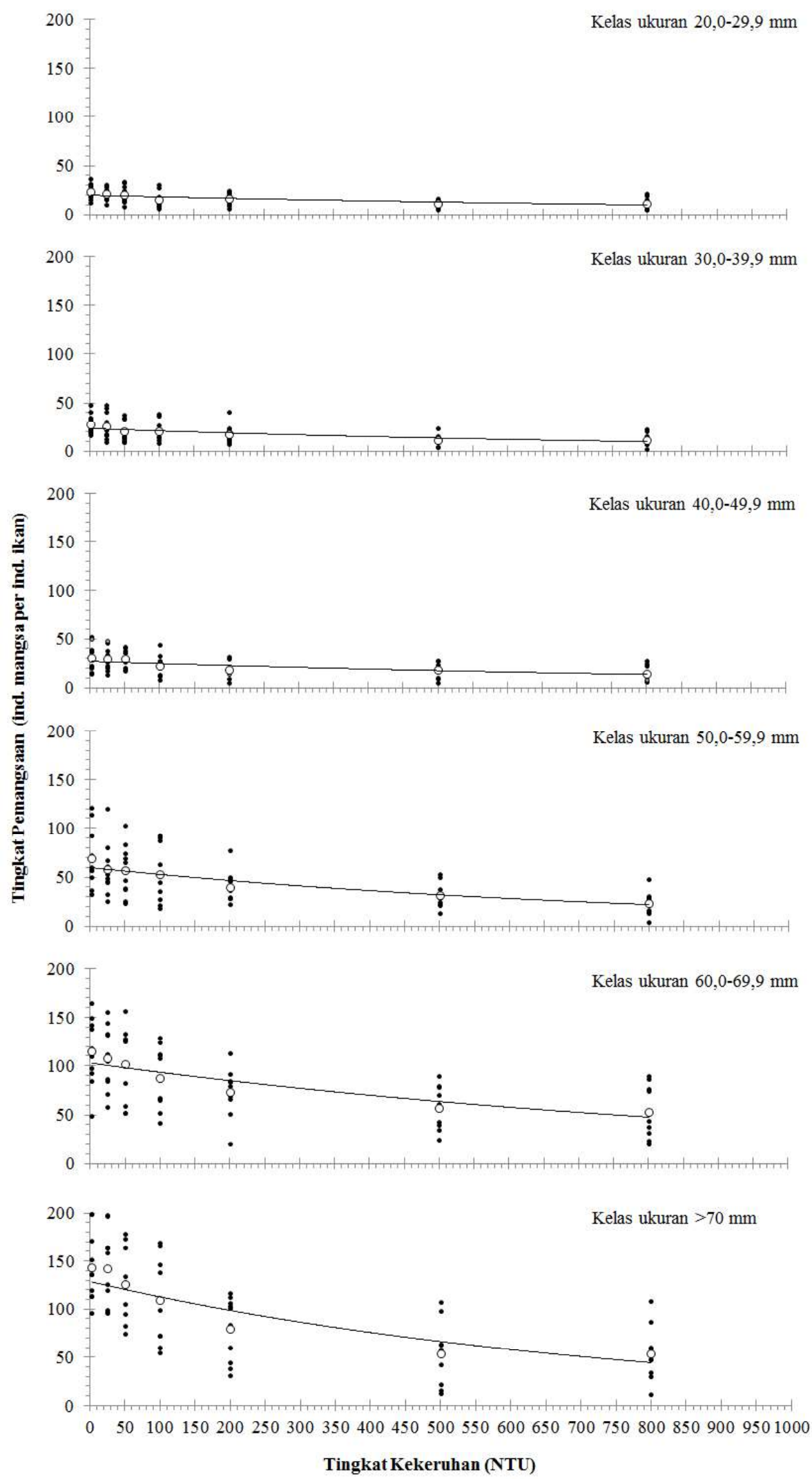

Gambar 1. Hubungan di antara tingkat pemangsaan dan tingkat kekeruhan pada enam kelas ukuran ikan pelangi arfak. Lingkaran hitam mewakili tingkat pemangsaan dalam 10 ulangan dan lingkaran putih menunjukkan tingkat pemangsaan rata-rata. Statistik regeresi ditampilkan pada Tabel 7. 


\section{Pembahasan}

Hasil penelitian ini menunjukkan bahwa tingkat kekeruhan air yang lebih besar dari 50,52 NTU sudah mulai memberikan dampak pada penurunan efektivitas mencari makan pada ikan pelangi arfak. Berdasarkan penelitian sebelumnya (Tapilatu \& Renyaan 2005, Manangkalangi 2009, Kadarusman et al. 2010), jenis ikan ini umumnya ditemukan pada perairan yang relatif jernih (<58,1 NTU). Keberadaan di perairan yang jernih juga dilaporkan pada beberapa jenis ikan pelangi lainnya (Kadarusman et al. 2010, Kadarusman et al. 2011, Allen \& Hadiaty 2013, Allen et al. 2014b), walaupun bisa ditemukan pada perairan yang keruh (Hattori \& Warburton 2003, Allen et al. 2014a). Keberadaan jenis ikan ini pada kondisi perairan yang jernih diduga berkaitan dengan efektivitasnya dalam mencari makan.

Beberapa penelitian sebelumnya menunjukkan berkurangnya efektivitas ikan dalam mencari makanan pada perairan yang keruh (Berg \& Northcote 1985, Bruton 1985, Vogel \& Beauchamp 1999, Sweka \& Hartman 2003, Sutherland \& Meyer 2007, Zamor \& Grossman 2007) karena jarak reaktif secara visual dan/atau kecepatan mencari makan yang menurun (Barrett et al. 1992, Rowe \& Dean 1998, Shoup \& Wahl 2009, Carter et al. 2010). Penurunan efektivitas mencari makan pada ikan selanjutnya akan berakibat terhadap penurunan laju pertumbuhan, kelimpahan serta penyebaran di habitat alaminya (Sigler et al. 1984, Berkman \& Rabeni 1987, Northcote 1995, Rowe et al. 2000, Mol \& Ouboter 2004).

Ikan pelangi arfak termasuk kelompok spesialis (Manangkalangi \& Kaliele 2011), terutama makan makroavertebrata air dari kelompok insekta dengan preferensi pada Diptera, Ephemeroptera, Coleoptera, dan Trichoptera (Manangkalangi et al. 2010). Selain berpengaruh langsung terhadap efektivitas ikan dalam mencari makan, peningkatan kekeruhan juga bisa berdampak negatif terhadap keberadaan makroavertebrata air sebagai makanan ikan. Peningkatan kekeruhan di perairan sungai akan berpengaruh terhadap kepadatan dan keanekaragaman makroavertebrata air serta akan mengubah struktur trofik pada ekosistem sungai (Growns \& Davis 1994, Henley et al. 2000, Gleason et al. 2003, Connolly \& Pearson 2007, Couceiro et al. 2010, 2011).

Penelitian Manangkalangi et al. (2015) menunjukkan bahwa habitat ikan pelangi arfak di beberapa lokasi (segmen bagian hilir) di Sungai Nimbai telah mengalami degradasi berkaitan dengan berkurangnya vegetasi hutan riparia di bagian tepi sungai sebagai akibat aktivitas antropogenik. Beberapa penelitian menunjukkan bahwa berkurangnya vegetasi riparia akan menyebabkan meningkatnya masukan partikel tersuspensi dan kekeruhan dalam sistem sungai (Growns \& Davis 1994, Sutherland et al. 2002, dos Santos et al. 2015). Kondisi ini diduga sebagai salah satu penyebab semakin berkurangnya habitat yang sesuai bagi ikan pelangi arfak di Sungai Nimbai (Manangkalangi et al. 2015). Oleh karena itu, perlindungan zona riparia yang masih ada dan restorasinya yang telah rusak perlu dilakukan sebagai salah satu upaya konservasi habitat alami (Wichert \& Rapport 1998, Pusey \& Arthington 2003, Lorion \& Kennedy 2009, Orzetti et al. 2010) untuk mempertahankan keberadaan populasi ikan endemik ini di alam.

\section{Simpulan}

Berdasarkan hasil penelitian ini dapat disimpulkan bahwa ikan pelangi arfak tidak mampu menoleransi kondisi kekeruhan air yang tinggi. Efektivitas ikan mencari makan mulai menurun pada tingkat kekeruhan yang lebih tinggi ( $\geq 100,12$ NTU). 


\section{Persantunan}

Penulis menyampaikan terima kasih kepada Frengky N. Krey, Bernadus Duwit, Satriano N. Yoku, dan Paskalina T. Lefaan yang telah membantu di lapangan dan di laboratorium dalam pengumpulan dan penanganan contoh ikan pelangi arfak serta larva nyamuk. Juga disampaikan terima kasih kepada Ridwan Sala atas diskusi terkait dengan analisis data, serta kepada Paulus Boli dan Yehiel H. Dasmasela selaku Kepala Laboratorium Perikanan dan Kepala Laboratorium Ilmu Kelautan FPIK UNIPA yang telah membantu menyediakan sarana dan prasarana dalam penelitian ini. Penulis juga menyampaikan terima kasih kepada Kementerian Riset, Teknologi dan Pendidikan Tinggi atas dukungan Beasiswa Pendidikan Pascasarjana Dalam Negeri (BPPDN) tahun 2014.

\section{Daftar pustaka}

Allen GR. 1990. Les poissons arc-en-ciel (Melanotaeniidae) de la Péninsule de Vogelkop, Irian Jaya, avec description de trois nouvelles espèces. Revue française d'Aquariologe, 16(4): 101-112.

Allen GR. 1991. Field guide to the freshwater fishes of New Guinea. Christensen Research Institute, Madang. 268 p.

Allen GR, Hadiaty RK. 2013. Melanotaenia sneideri, a new species of rainbowfish (Melanotaeniidae), from West Papua Province, Indonesia. Aqua, 19(3): 137-146.

Allen GR, Hadiaty RK, Unmack PJ. 2014a. Melanotaenia flavipinnis, a new species of rainbowfish (Melanotaeniidae) from Misool Island, West Papua Province, Indonesia. Aqua, 20(1): 35-52.

Allen RG, Unmack PJ, Hadiaty RK. 2014 b. Three new species of rainbowfishes (Melanotaeniidae) from the Birds Head Peninsula, West Papua Province, Indonesia. Aqua, 20(3): 139-158.

Barrett JC, Grossman GD, Rosenfeld J. 1992. Turbidity-induced changes in reactive distance of rainbow trout. Transactions of the
American Fisheries Society, 121(4): 437443.

Batsaikhan B, Kwon J-S, Kim K-H, Lee Y-J, Lee J-H, Badarch M, Yun S-T. 2017. Hydrochemical evaluation of the influences of mining activities on river water chemistry in central northern Mongolia. Environmental Science and Pollution Research, 24(2): 2019-2034.

Berg L, Northcote TG. 1985. Changes in territorial, gill-flaring, and feeding behavior in juvenile coho salmon (Oncorhynchus kisuth) following short-term pulses of suspended sediment. Canadian Journal of Fisheries and Aquatic Sciences, 42(8): 1410-1417.

Berkman HE, Rabeni CF. 1987. Effects of siltation on stream fish communities. Environmental Biology of Fishes, 18(4): 285-294.

Bhattacharjee I, Aditya G, Chandra G. 2009. Laboratory and field assessment of the potential of larvivorous, air-breathing fishes as predators of culicine mosquitoes. Biological Control, 49(2): 126-133.

Binur R, Budirianto HJ. 2008. Potensi populasi ikan pelangi arfak (Melanotaenia arfakensis Allen, 1990) di Sungai Wariori Kawasan Cagar Alam Pegunungan Arfak dalam upaya konservasi secara in-situ. Jurnal Perikanan dan Kelautan, 4(2): 151-159.

Bojsen BH, Barriga R. 2002. Effects of deforestation on fish community structure in Ecuadorian Amazon streams. Freshwater Biology, 47(11): 2246-2260.

Bonner TH, Wilde GR. 2002. Effects of turbidity on prey consumption by prairie stream fishes. Transactions of the American Fisheries Society, 131(6): 1203-1208.

Bruton MN. 1985. The effects of suspensoids on fish. Hydrobiologia, 125(1): 221-241.

Carter MW, Shoup DE, Dettmers JM, Wahl DH. 2010. Effects of turbidity and cover on prey selectivity o-f adult smallmouth bass. Transactions of the American Fisheries Society, 139(2): 353-361.

Casatti L, Ferreira CP, Carvalho FR. 2009. Grass-dominated stream sites exhibit low fish species diversity and dominance by guppies: an assessment of two tropical pasture river basins. Hydrobiologia, 632(1): 273-283.

Colless DH, McAlpine DK. 1996. Diptera (flies). In: Naumann ID, Carne PB, Lawrence JF, Nielsen ES, Spradbery JP, Taylor RW, 
Whitten MJ, Littlejohn MJ (eds). The Insects of Australia: A textbook for students and research workers. Volume II. Melbourne University Press. pp. 717-786.

Connolly NM, Pearson RG. 2007. The effect of fine sedimentation on tropical stream macroinvertebrate assemblages: a comparison using flow-through artificial stream channels and recirculating mesocosms. Hydrobiologia, 592: 423-438.

Couceiro SRM, Hamada N, Forsberg BR, Padovesi-Fonseca C. 2010. Effects of anthropogenic silt on aquatic macroinvertebrates and abiotic variables in streams in the Brazilian Amazon. Journal of Soils and Sediments, 10(1): 89-103.

Couceiro SRM, Hamada N, Forsberg BR, Padovesi-Fonseca C. 2011. Trophic structure of macroinvertebrates in Amazonian streams impacted by antropogenic siltation. Austral Ecology, 36(6): 628-637.

Crowl TA. 1989. Effects of crayfish size, orientation, and movement on the reaction distance of largemouth bass foraging in clear and turbid water. Hydrobiologia, 183(2): 133-140.

dos Santos FB, Ferreira FC, Esteves KE. 2015. Assessing the importance of the riparian zone for stream fish communities in a sugarcane dominated landscape (Piracicaba River Basin, Southeast Brazil). Environmental Biology of Fishes, 98(8): 1895-1912.

Giam X, Hadiaty RK, Tan HH, Parenti LR, Wowor D, Sauri S, Chong KY, Yeo DCJ, Wilcove DS. 2015. Mitigating the impact of oilpalm monoculture on freshwater fishes in Southeast Asia. Conservation Biology, 29(5): 1357-1367.

Gleason RA, Euliss Jr. NH, Hubbard DE, Duffy WG. 2003. Effects of sediment load on emergence of aquatic invertebrates and plants from wetland soil egg and seed banks. Wetlands. 23 (1): 26-34.

Growns IO, Davis JA. 1994. Effects of forestry activity (clearfelling) on stream macroinvertebrate fauna in south-western Australia. Australian Journal of Marine and Freshwater Research, 45(6): 963-975.

Gupta S, Banerjee S. 2013. Comparative assessment of mosquito biocontrol efficiency between guppy (Poecilia reticulata) and panchax minnow (Aplocheilus panchax). Bioscience Discovery, 4(1): 89-95.
Hattori A, Warburton K. 2003. Microhabitat use by the rainbowfish Melanotaenia duboulayi in a subtropical Australian stream. Journal of Ethology, 21: 15-22.

Henley WF, Patterson MA, Neves RJ, Lemly AD. 2000. Effects of sedimentation and turbidity on lotic food webs: a concise review for natural resource managers. Reviews in Fisheries Science, 8(2): 125-139.

Iwata T, Nakano S, Inoue M. 2003. Impacts of past riparian deforestation on stream communities in a tropical rain forest in Borneo. Ecological Applications, 13(2): 461-473.

Jacob SS, Nair NB, Balasubramanian NK. 1983. Influence of certain environmental factors on the predatory efficiency of the larvivorous fish Macropodus cupanus. Environmental Biology of Fishes, 9(3-4): 295-300.

Kadarusman, Sudarto, Paradis E, Pouyaud L. 2010. Description of Melanotaenia fasinensis, a new species of rainbowfish (Melanotaeniidae) from West Papua, Indonesia with comments on the rediscovery of M. Ajamaruensis and the endagered status of $M$. parva. Cybium, 34(2): 207-215.

Kadarusman, Sudarto, Slembrouck J, Pouyaud L. 2011. Description of Melanotaenia salawati, a new species of rainbowfish (Melanotaeniidae) from Salawati Island, West Papua, Indonesia. Cybium, 35(3): 223-230.

Kadarusman, Hubert N, Hadiaty RK, Sudarto, Paradis E, Pouyaud L. 2012. Cryptic diversity in Indo-Australian rainbowfishes revealed by DNA barcoding: implications for conservation in a biodiversity hotspot candidate. Plos ONE, 7(7): e40627.

Lenzi MA, Marchi L. 2000. Suspended sediment load during floods in a small stream of the Dolomites (northeastern Italy). Catena, 39: 267-282.

Lobón-Cerviá J, Mazzoni R, Rezende CF. 2016. Effects of riparian forest removal on the trophic dynamics of a Neotropical stream fish assemblage. Journal of Fish Biology, 89(1): 50-64.

Lorion CM, Kennedy BP. 2009. Riparian forest buffers mitigate the effects of deforestation on fish assemblages in tropical headwater streams. Ecological Applications, 19(2): 468479.

Manangkalangi E. 2009. Makanan, pertumbuhan dan reproduksi ikan pelangi arfak (Melanota- 
enia arfakensis Allen) di Sungai Nimbai dan Sungai Aimasi, Manokwari. Tesis. Program Pascasarjana, Institut Pertanian Bogor. 105 hlm.

Manangkalangi E, Pattiasina TF. 2005. Studi pendahuluan aspek reproduksi dan pertumbuhan ikan rainbow (melanotaeniidae) di perairan tawar Distrik Kebar Kabupaten Manokwari. Jurnal Perikanan dan Kelautan, 1(2): 87-94.

Manangkalangi E, Rahardjo MF, Sjafii DS. 2009a. Habitat ontogeni ikan pelangi arfak (Melanotaenia arfakensis) di Sungai Nimbai dan Sungai Aimasi, Manokwari. Jurnal Natural, 8(1): 4-11.

Manangkalangi E, Rahardjo MF, Sjafii DS, Sulistiono. 2009b. Musim pemijahan ikan pelangi arfak (Melanotaenia arfakensis Allen) di Sungai Nimbai dan Sungai Aimasi, Manokwari. Jurnal Iktiologi Indonesia, 9(1): 1-12.

Manangkalangi E, Rahardjo MF, Sjafii DS, Sulistiono. 2010. Preferensi makanan ikan pelangi arfak (Melanotaenia arfakensis Allen, 1990) di Sungai Nimbai dan Sungai Aimasi, Manokwari. Jurnal Iktiologi Indonesia, 10(2): 123-135.

Manangkalangi E, Kaliele MY. 2011. Luas relung, tumpang tindih dan strategi mencari makan ikan pelangi arfak (Melanotaenia arfakensis) dan ikan pemakan nyamuk (Gambusia affinis) di Sungai Nimbai, Manokwari. Jurnal Perikanan dan Kelautan, 7(2): 153-164.

Manangkalangi E, Leatemia SPO, Lefaan PT, Peday HFZ, Sembel L. 2014. Kondisi habitat ikan pelangi arfak, Melanotaenia arfakensis, 1990 di Sungai Nimbai, Prafi Manokwari. Jurnal Iktiologi Indonesia, 14(1): 21-36.

Manangkalangi E, Leatemia SPO, Lefaan PT, Peday HFZ, Sembel L. 2015. Potensi ikan pelangi arfak Melanotaenia arfakensis Allen 1990 sebagai biokontrol larva nyamuk. Jurnal Iktiologi Indonesia, 15(2): 107-117.

Mercer EV, Mercer TG, Sayok AK. 2013. Effects of forest conversions to oil palm plantations on freshwater macroinvertebrates: a case study from Sarawak, Malaysia. Journal of Land Use Science, 9(3): 260-277.

Mol JH, Ouboter PE. 2004. Downstream effects of erosion from small-scale gold mining on the instream habitat and fish community of a small neotropical rainforest stream. Conservation Biology. 18(1): 201-214.
Mori GB, de Paula FR, de Barros Ferraz SF, Camargo AFM, Martinelli LA. 2015. Influence of landscape properties on stream water quality in agricultural catchments in southeastern Brazil. Annales de Limnologie, 51(1): 11-21.

Northcote TG. 1995. Comparative biology and management of Arctic and European grayling (Salmonidae, Thymallus). Reviews in Fish Biology and Fisheries, 5(2): 141-194.

Orzetti LL, Jones RC, Murphy RF. 2010. Stream condition in Piedmont streams with restored riparian buffers in the Chesapeake Bay watershed. Journal of the American Water Resources Association, 46(3): 473-485.

Pusey BJ, Arthington AH. 2003. Importance of riparian zone to the conservation and management of freshwater fish: a review. Marine and Freshwater Research, 54(1): 1-16.

Rowe DK, Dean TL. 1998. Effects of turbidity on the feeding ability of the juvenile migrant stage of six New Zealand freshwater fish species. New Zealand Journal of Marine and Freshwater Research. 32(1): 21-29.

Rowe D, Hick M, Richardson J. 2000. Reduced abundance of banded kokopu (Galaxias fasciatus) and other native fish in turbid rivers of the North Island of New Zealand. New Zealand Journal of Marine and Freshwater Research. 34(3): 547-558.

Russell BM, Wang J, Williams Y, Hearnden MN, Kay BH. 2001. Laboratory evaluation of two native fishes from tropical North Queensland as biological control agents of subterranean Aedes aegypti. Journal of the American Mosquito Control Association, 17(2): 124-126.

Sabariah V. 2004. Infeksi parasit copepoda: cacing jangkar (Lernea sp.) pada ikan pelangi arfak (Melanotaenia arfakensis). Prosiding Pengendalian Penyakit pada Ikan dan Udang Berbasis Imunisasi dan Biosecurity. Seminar Nasional IV Penyakit Ikan dan Udang. Purwokerto 18-19 Mei 2004. Hal. 38-41.

Sabariah V, Simatauw F, Kopalit H. 2005. Ektoparasit dan endoparasit ikan rainbow (Melanotaenia arfakensis) dari Sungai Nuni-Manokwari. Jurnal Perikanan dan Kelautan, 1(2): 95-101.

Sabariah V, Manangkalangi E, Kopalit H. 2006a. Variasi musim dan geografis parasit ikan rainbow arfak (Melanotaenia arfakensis) 
pada beberapa sungai di Manokwari. Jurnal Perikanan dan Kelautan, 2(1): 67-78.

Sabariah V, Manangkalangi E, Zainuddin F. 2006b. Kebiasaan makanan ikan pelangi arfak (Melanotaenia arfakensis) dari perairan Sungai di Kebar dan Prafi-Manokwari. Prosiding Seminar Nasional Ikan IV, Jatiluhur 29-30 Agustus 2005. pp. 19-23.

Saleeza SNR, Norma-Rashid Y, Sofian-Azirun M. 2014. Guppies as predators of common mosquito larvae in Malaysia. The Southeast Asian Journal of Tropical Medicine and Public Health, 45(2): 299-308.

Shoup DE, Wahl DH. 2009. The effects of turbidity on prey selection by piscivorous largemouth bass. Transactions of the American Fisheries Society, 138(5): 1018-1027.

Sigler JW, Bjornn TC, Everest FH. 1984. Effects of chronic turbidity on density and growth of steelhead and coho salmon. Transactions of the American Fisheries Society. 113(2): 142150 .

Sutherland AB, Meyer JL, Gardiner EP. 2002. Effects of land cover on sediment regime and fish assemblage structure in four southern Appalachian streams. Freshwater Biology, 47(9): 1791-1805.

Sutherland AB, Meyer JL. 2007. Effects of increased suspended sediment on growth rate and gill condition of two southern Appalachian minnows. Environmental Biology of Fishes, 80(4): 389-403.

Sweka JA, Hartman KJ. 2003. Reduction of reaction distance and foraging success in smallmouth bass, Micropterus dolomieu, exposed to elevated turbidity levels. Environmental Biology of Fishes, 67(4): 341-347.

Tapilatu RF, Renyaan AWA. 2005. Kajian aspek morfologis rainbowfish arfak (Melanotaenia arfakensis) pada habitat aslinya di beberapa daerah aliran sungai dalam kawasan lindung
Pegunungan Arfak Manokwari. Jurnal Perikanan dan Kelautan, 1(2): 79-86.

Uthe-Palm AC. 1999. The effect of prey mobility, prey contrast, turbidity and spectral composition on the reaction distance of Gobiusculus flavescens to its planktonic prey. Journal of Fish Biology, 54(6): 1244-1258.

Vogel JL, Beauchamp DA. 1999. Effects of light, prey size, and turbidity on reaction distances of lake trout (Salvelinus namaycush) to salmonid prey. Canadian Journal of fisheries and Aquatic Sciences, 56(7): 1293-1297.

Walling DE, Owens PN, Waterfall BD, Leeks GJL, Wass PD. 2000. The particle size characteristics of fluvial suspended sediment in the Humber and Tweed catchments, UK. The Science of the Total Environment, 251252: 205-222.

Wang J, Edwards PJ, Wood F. 2013. Turbidity and suspended-sediment changes from stream-crossing construction on a forest haul road in West Virginia, USA. International Journal of Forest Engineering, 24(1): 76-90.

Wichert GA, Rapport DJ. 1998. Fish community structure as a measure of degradation and rehabilitation of riparian systems in an agricultural drainage basin. Environmental Management, 22(3): 425-443.

Willems KJ, Webb CE, Russell RC. 2005. A comparison of mosquito predation by the fish Pseudomugil signifer Kner and Gambusia holbrooki (Girard) in laboratory trials. Journal of Vector Ecology, 30(1): 87-90.

Wright JP, Flecker AS. 2004. Deforesting the riverscape: the effects of wood on fish diversity in a Venezuelan piedmont stream. Biological Conservation, 120(3): 439- Zamor RM, Grossman GD. 2007. Turbidity affects foraging success of drift-feeding rosyside dace. Transactions of the American Fisheries Society, 136(1): 167-176. 